\title{
Pemanfaatan energi terbarukan dalam upaya swasembada listrik di kawasan wisata edukasi pedesaan
}

\author{
Lanny Agustine ${ }^{1 *}$, Albert Gunadhi ${ }^{2}$, Diana L. Antonia ${ }^{3}$, Widya A. \\ Weliamto ${ }^{4}$, Peter R. Angka ${ }^{5}$, Rasional Sitepu ${ }^{6}$, Hartono Pranjoto ${ }^{7}$, Andrew \\ Joewono $^{8}$, Yuliati $^{9}$, Andrew F. Miyata ${ }^{10}$
}

\footnotetext{
${ }^{1}$ Universitas Katolik Widya Mandala Surabaya, Indonesia, email: lanny.agustine@ukwms.ac.id

2Universitas Katolik Widya Mandala Surabaya, Indonesia, email: albert@ukwms.ac.id

3Universitas Katolik Widya Mandala Surabaya, Indonesia, email: diana@ukwms.ac.id

${ }^{4}$ Universitas Katolik Widya Mandala Surabaya, Indonesia, email:widya_andy@yahoo.com

5 Universitas Katolik Widya Mandala Surabaya, Indonesia, email:peter@ukwms.ac.id

6Universitas Katolik Widya Mandala Surabaya, Indonesia, email: rasional@ukwms.ac.id

${ }^{7}$ Universitas Katolik Widya Mandala Surabaya, Indonesia, email: pranjoto@ukwms.ac.id

${ }^{8}$ Universitas Katolik Widya Mandala Surabaya, Indonesia, email: andrew_sby@ukwms.ac.id

9Universitas Katolik Widya Mandala Surabaya, Indonesia, email: yuliati@ukwms.ac.id

${ }^{10}$ Universitas Katolik Widya Mandala Surabaya, Indonesia, email: andrewfebrian3@gmail.com

*Koresponden penulis
}

\section{Info Artikel}

Diajukan: 24 Jun 2021

Diterima: 07 Nov 2021

Diterbitkan: 20 Nov 2021

Keywords:

educational tourism; Solar energy; Self-sufficiency

Kata Kunci:

wisata pendidikan; tenaga surya; swasembada

Lisensi:

cc-by-sa

\begin{abstract}
Cottok Innovation Park (CIP) is a tourist area that develops technology-based educational tourism. CIP is located on a broad hill. This area was in a barren state when the first service activities were carried out at the beginning of development in 2017. The PLN electricity network is also not yet available because it is far from residential areas. Solar-based technology has been applied and developed sustainably at CIP as an effort to be self-sufficient in electrical energy to provide water and lighting. Water is obtained by a solar pump from a groundwater source at a depth of $40 \mathrm{~m}$. Currently, CIP has grown rapidly and provides night tours. The latest community service activities results are off-grid PLTS-based road signs and the CIP icon lamp to support night tourism. A further effect of this sustainable community service activity is the motivation and confidence of village youth to be involved in village development programs as tourist areas and children's education. It has also impacted the decline in the number of poor people in the village of Curah Cottok.
\end{abstract}

\section{Abstrak}

Cottok Innovation Park (CIP) merupakan kawasan wisata yang mengembangkan wisata pendidikan berbasis teknologi. CIP terletak diatas bukit yang luas. Kawasan ini dalam keadaan tandus saat kegiatan pengabdian pertama dilakukan diawal pengembangan pada tahun 2017. Jaringan listrik PLN juga belum tersedia hingga saat ini karena jauh dari pemukiman warga. Teknologi berbasis tenaga surya telah diterapkan dan dikembangkan secara berkelanjutan di CIP sebagai upaya swasembada energi listrik untuk menyediakan air dan penerangan. Air diperoleh dengan pompa tenaga surya dari sumber air tanah di kedalaman $40 \mathrm{~m}$. Saat ini CIP telah berkembang pesat dan menyediakan wisata malam. Hasil dari kegiatan pengabdian masyarakat terbaru adalah lampu penunjuk jalan berbasis PLTS off grid dan lampu ikon CIP untuk menunjang wisata malam. Efek lanjut 
dari kegiatan pengabdian masyarakat yang berkesinambungan ini yaitu timbulnya motivasi dan rasa percaya diri kaum muda desa untuk terlibat dalam program pengembangan desa sebagai kawasan wisata dan pendidikan anak. Ini juga berdampak pada turunnya jumlah masyarakat miskin di desa Curah Cottok.

\section{PENDAHULUAN}

Desa Curah Cottok, Kec. Kapongan, Kab. Situbondo, Jatim dengan 565 kepala keluarga mayoritas mata pencahariannya di bidang pertanian yaitu $27 \%$ petani dan $40 \%$ buruh tani. Pada tahun 2017 sebanyak 80 persen warga desa Curah Cottok tergolong miskin. Banyak lahan kering dan tandus karena hanya mengandalkan air hujan sehingga tidak dapat ditanami untuk kegiatan pertanian (Anggorowati et al., 2021; Darma, 2018). Sebagaimana desa lainnya di Indonesia, di desa Curah Cottok pun masih terdapat daerah yang belum terjangkau oleh jaringan PLN, terutama di area pertanian seperti di kawasan bukit Cottok (Bappeda Provinsi Jawa Timur, 2013). Namun demikian, terdapat sejumlah potensi dari desa tersebut. Lahan yang tandus itu cukup luas dan dapat dimanfaatkan menjadi tempat inovasi berkelanjutan, baik sebagai tempat wisata, wahana pendidikan berbasis pertanian atau peternakan, dan sebagainya. Pada lahan tandus tersebut juga terdapat sumber air tanah yang dapat dijadikan sumur dengan cara mengebor ke kedalaman tanah (Sitorus, 2016; Sulistyaningsih \& Yekti, 2017).

Peluang peningkatan kesejahteraan masyarakat desa Curah Cottok cukup besar jika dilakukan melalui pendekatan inovasi berkelanjutan. Salah satu inovasi yang pertama kali perlu dilakukan adalah pengembangan infrastruktur terutama untuk penyediaan energi listrik. Dengan adanya energi listrik, maka pompa listrik dapat digunakan untuk menaikkan air tanah ke atas bukit Cottok. Listrik tersebut juga dapat dijadikan energi penerangan pada malam hari sehingga kawasan tidak lagi menjadi angker karena gelap, melainkan menjadi kawasan yang ramah bagi masyarakat. Desa Curah Cottok harus mengupayakan swasembada energi listrik karena bukit Cottok bukan area pemukiman penduduk sehingga tidak tersedia jaringan PLN. Untuk itu, perlu alternatif sumber energi listrik di kawasan tersebut. Saat ini sudah tersedia berbagai jenis energi terbarukan yang dapat dimanfaatkan untuk swasembada energi listrik v(Naim, 2017; Roza \& Mujirudin, 2019). Kebijakan energi nasional telah mendukung penggunaan energi terbarukan dengan menetapkan sasaran $23 \%$ kapasitas energi menggunakan sumber energi baru dan terbarukan (EBT) pada tahun 2025, dan naik menjadi $31 \%$ pada tahun 2050. Pemanfaatan EBT terus didorong agar dapat menekan emisi gas CO2 di udara (Kementerian ESDM RI, 2018).

Kesadaran masyarakat untuk berpartisipasi mengurangi pemanasan global dan polusi dengan memanfaatkan energi yang lebih bersih sudah makin meningkat (Kementerian ESDM RI, 2020), demikian halnya dengan perangkat desa Curah Cottok. Potensi energi dari Pembangkit Listrik Tenaga Surya (PLTS) di Jawa Timur dapat mencapai 10.335 MW. PLN mempunyai target untuk realisasi PLTS pada tahun 2019-2028 dengan kapasitas $250 \mathrm{MW}$ (Arinaldo \& Christian, 2018). Desa ini dan sekitarnya rata-rata per tahun hanya 
mengalami 4 bulan musim penghujan. Dengan curah hujan yang demikian sedikit, maka lahan pertanian cenderung tandus, sehingga cukup banyak lahan terbuka dengan pancaran matahari cukup terik sejak pagi hingga menjelang sore hari. Kondisi daerah seperti ini sangat cocok untuk aplikasi teknologi tenaga surya (Anggorowati et al., 2021; Bappeda Provinsi Jawa Timur, 2013). Kondisi ini sangat mendukung untuk terlaksananya konservasi energi yang berkelanjutan.

Berdasarkan analisa kondisi desa Curah Cottok tersebut, sejak awal 2018 telah dicanangkan pengembangan bukit Cottok menjadi Cottok Innovation Park (CIP). CIP dipersiapkan menjadi tempat wisata berbasis pendidikan agar masyarakat dapat belajar teknologi terbaru, salah satunya pembangkit listrik tenaga surya (PLTS), dan berinovasi secara berkelanjutan di kawasan tersebut. Pengembangan tersebut direncanakan dengan melibatkan berbagai pihak melalui kegiatan bina desa dan pengabdian masyarakat. Untuk merealisasikan CIP, Kepala Desa Curah Cottok bekerjasama dengan Program Studi Teknik Elektro Universitas Katolik Widya Mandala Surabaya (PS-TE UKWMS) dan Badan Usaha Milik Desa (BUMDes) (Putra, 2018). PS-TE UKWMS selanjutnya mengadakan sejumlah kegiatan pengabdian masyarakat untuk pengembangan bukit Cottok.

Pada kegiatan pengabdian masyarakat terdahulu, telah dilakukan pengenalan tentang teknologi tenaga surya hingga implementasinya. Untuk mendukung cita-cita pemerintah desa menciptakan lapangan usaha baru berbasis teknologi, maka perlu diberikan pelatihan serupa kepada lebih banyak lagi kelompok warga yang belum berkesempatan mengikuti kegiatan terdahulu. Untuk itu, dengan kegiatan kali ini masih difokuskan pada transfer technical knowledge pada kaum muda di desa Curah Cottok untuk mengaplikasikan teknologi tenaga surya di desa tersebut. Dengan demikian, lebih banyak lagi kaum muda desa dapat termotivasi dan terlibat dalam upaya pengembangan swasembada energi listrik di desa Curah Cottok, dan impian tersedianya lapangan usaha baru berbasis teknologi dapat terwujud.

\section{METODE PELAKSANAAN}

Metode pelaksanaan kegiatan pengabdian pada masyarakat kali ini terdiri dari beberapa tahap. Tahap persiapan diawali dengan penggalian ide topik yang tepat untuk diberikan. Tahap ini merupakan hasil dari evaluasi kegiatan abdimas sebelumnya dan diskusi lebih lanjut dengan perangkat desa. Rencana pembuatan lampu penunjuk jalan berbasis PLTS merupakan ide yang disampaikan oleh pihak desa di kegiatan abdimas sebelumnya. Ada dua hal yang mendasari ide tersebut. Pertama, bukit Cottok telah berkembang menjadi kawasan wisata yang menyediakan berbagai wahana wisata untuk pagi maupun malam hari. Kedua, jalan masuk dari desa menuju bukit Cottok cukup jauh dan melewati area diluar pemukiman penduduk dan tidak tersedia jaringan PLN. Berdasarkan pemikiran tersebut dan hasil diskusi dengan perangkat desa, maka muncul ide untuk membuat penunjuk jalan yang dilengkapi dengan penerangan dengan sumber daya mandiri berbasis PLTS. Kemudian, dilakukan pengumpulan informasi tentang situasi lokasi yang menjadi sasaran aplikasi 
lampu penunjuk jalan yang strategis dilewati pengunjung ke arah bukit Cottok sehingga efektif untuk penunjuk arah, menarik untuk dilihat, dan dapat terlihat jelas dari jalan yang dilewati pengunjung pada siang maupun malam hari. Penempatan lampu penunjuk jalan berbasis PLTS didiskusikan dengan perangkat desa sehingga sesuai dengan kebutuhan di lokasi.

Tahap selanjutnya adalah perancangan dan realisasi bagian-bagian lampu penunjuk jalan berbasis tenaga surya dan lampu ikon CIP yang melibatkan sejumlah 9 mahasiswa. Bagian-bagian kerangka lampu penunjuk jalan dikerjakan terlebih dahulu di kampus, dan pengujian terhadap komponen juga dilakukan sebelum pengiriman perangkat ke lokasi CIP. Lampu ikon CIP didesain menggunakan bahan warna-warni sesuai logo tempat wisata tersebut. Pada tahap ini juga dibuat modul yang berisi penjelasan bagian-bagian alat dan kegunaannya, metode perhitungan desain dan pemilihan bagian-bagian alat sesuai kebutuhan, serta cara perakitan lampu penunjuk jalan berbasis tenaga surya.

Tahap akhir yaitu implementasi dan instalasi hasil rancangan dan perakitan lampu penunjuk jalan berbasis energi surya pada jalan desa menuju bukit CIP dan lampu ikon CIP di puncak bukit area pintu masuk tempat wisata. Pada tahap ini peserta dibagi dalam kelompok. Masing-masing kelompok didampingi oleh 1 orang mahasiswa dan dalam pengawasan dosen. Hal ini ditujukan agar peserta dapat lebih fokus dan lebih bebas bereksplorasi untuk mendalami bagian-bagian peralatan yang umum digunakan bersama penerapan teknologi pembangkit listrik tenaga surya. Pada akhir sesi pelatihan, peserta dan tim pengabdian masyarakat berkumpul kembali untuk melakukan evaluasi kegiatan melalui pengisian kuesioner dan wawancara sebagai masukan untuk tindak lanjut kegiatan abdimas ini.

\section{HASIL DAN PEMBAHASAN}

Setiap kegiatan yang diberikan dalam pengabdian masyarakat akan mengangkat aplikasi yang paling dibutuhkan untuk pengembangan desa. Peserta kegiatan diatur agar mayoritas terdiri dari kaum muda desa yang berbeda-beda. Ini bertujuan untuk membuka wawasan lebih banyak anggota masyarakat tentang teknologi tepat guna yang dapat diterapkan oleh dan untuk masyarakat desa. Kaum muda diajak untuk berpikir, sehingga wawasannya lebih terbuka dan nantinya mampu mengimplementasikan teknologi tepat guna yang sudah dipelajari untuk meningkatkan perekonomian di desa tersebut. Dari implementasi teknologi tepat guna tersebut, kaum muda akan ditantang lebih lanjut untuk mengkomersialkannya, dan pada akhirnya kaum muda dapat berwiraswasta untuk mengembangkan perekonomian desa di lingkungan bukit Cottok.

Kegiatan abdimas masyarakat kali ini berupa pemanfaatan listrik tenaga surya lampu penunjuk jalan ke Kawasan CIP. Dari kegiatan kali ini diharapkan dapat memberikan solusi yang dapat menjadi awal dari terbentuknya kelompok desa yang menguasai aplikasi teknologi tenaga surya dan timbulnya motivasi dan keahlian pada kaum muda desa untuk memanfaatkan tenaga surya bagi pengembangan desa sebagai kawasan wisata dan alternatif usaha 
(Sulistyaningsih \& Yekti, 2017). Rancangan bentuk lampu penunjuk jalan dan posisi panel surya serta papan penunjuknya dapat dilihat pada Gambar 1 dan Gambar 2. Perencanaan awal lampu ini adalah ukuran yang kecil namun cukup jelas terlihat dan menarik, serta mampu bertahan menyala hingga sebelum tengah malam. Untuk keperluan tersebut maka digunakan lampu LED pita yang hemat daya dan mudah dibentuk. LED pita direkatkan mengelilingi bahan akrilik $3 \mathrm{~mm}$ dengan bentuk tanda panah. Desain bentuk ini dipilih karena selain untuk memberi tanda arah juga mempertimbangkan estetika, sehingga menarik bagi pengunjung yang memasuki desa tersebut.

Bagian yang paling berat dari desain ini adalah komponen panel surya dan aki dengan total berat $2 \mathrm{~kg}$. Untuk kemudahan desain kelistrikan, maka perangkat panel surya dipasang pada ketinggian tiang penyangga $1,5 \mathrm{~m}$. Penyangga tersebut menggunakan pipa paralon 5 dim (diameter luar $14 \mathrm{~cm}$ ) dan bagian atasnya diberi rangka penyangga panel surya dari bahan alumunium. Pada rancangan ini digunakan panel surya dengan daya 10 WP. Desain penempatan panel surya pada rangka penyangga dan tiang dapat dilihat pada Gambar 1a. Panel surya dipasang pada bagian atas pipa paralon $5 \mathrm{dim}$ menggunakan tutup paralon DV. Pada saat instalasi, kemiringan panel surya disesuaikan dengan 15 derajat pada arah Barat.

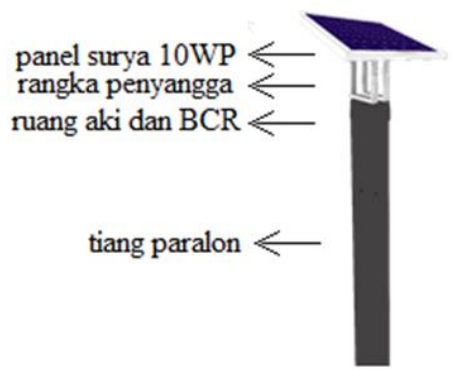

Gambar 1. Rancangan penempatan panel surya pada pipa paralon untuk lampu penunjuk jalan berbasis tenaga surya

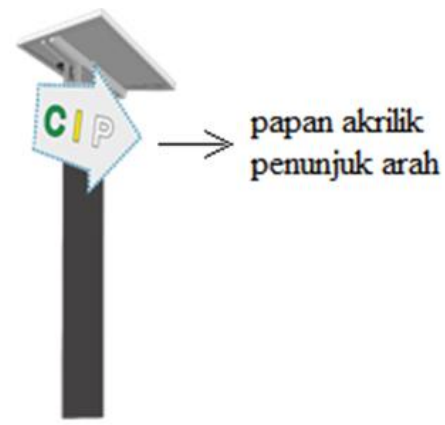

Gambar 2. Rancangan penempatan papan penunjuk jalan dengan LED pita

Perangkat tambahan berupa aki dan Battery Charge Controller (BCR) diletakkan di dalam pipa tersebut sehingga terlihat rapi dan aman dari air hujan. Bentuk lengkap dari lampu penunjuk jalan dengan papan akrilik bertuliskan CIP 
dan juga LED pita yang dilekatkan disekitar papan dapat dilihat pada Gambar 2. Papan penunjuk tersebut harus ditempatkan pada area yang bebas dari penghalang pancaran sinar matahari ke panel surya, dan juga dapat dilihat dengan jelas dari kejauhan.

Lokasi wisata CIP berada pada 7,7 derajat Lintang Selatan, sehingga tempat tersebut selalu mendapatkan intensitas radiasi matahari yang terik dengan radiasi rata-rata sebesar 4,8 kWh per hari (Prajogo et al., 2018; Roza \& Mujirudin, 2019). Radiasi tersebut tidak berubah sepanjang tahun, terlepas dari posisi matahari terhadap bumi yang dapat bergeser ke utara dan ke selatan di seluruh wilayah Indonesia. Dengan daya radiasi tersebut, perkiraan charging time bisa mencapai 6 jam per hari, sehingga menggunakan panel surya dengan daya 10 WP sudah mencukupi untuk beban LED pita yang digunakan. Gambar 3 adalah rangkaian lampu penunjuk jalan yang berdiri sendiri (off grid) yang terdiri dari panel surya, regulator baterai atau Battery Charge Controller (BCR), baterai, dan beban DC (Naim, 2017; Prajogo et al., 2018; Roza \& Mujirudin, 2019). Pada implementasi ini menggunakan aki kering 12 Volt 7 Ah dan LED pita DC 12 Volt dengan daya 5 Watt per meter sebagai beban.

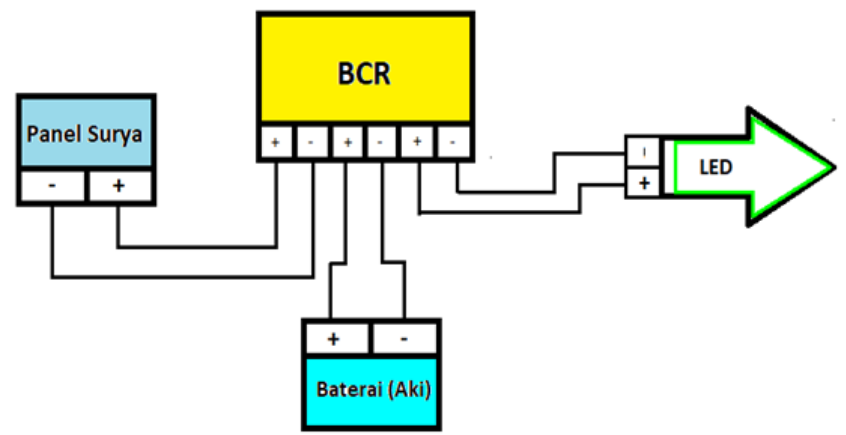

Gambar 3. Bagian-bagian penyusun lampu penunjuk jalan dan hubungan perkabelannya

BCR adalah sebuah perangkat elektronik yang mengontrol jumlah listrik yang masuk dan keluar dari baterai. BCR juga mengatur agar kinerja baterai optimal dan efisien, sehingga arus yang masuk dan keluar tidak terlalu besar dan tidak berpotensi merusak baterai tersebut. Suatu sistem dengan panel surya dan baterai hampir selalu dipasang dengan menggunakan BCR untuk melindungi baterai dari berbagai jenis batasan, diantaranya yaitu pengisian daya berlebih, pengisian secara berkala pada saat baterai penuh (trickle charge), arus bocor kembali ke panel surya pada malam hari, dan pencegahan pengurasan arus baterai berlebih (Ramadhan et al., 2016; Rif'an et al., 2012; Roza \& Mujirudin, 2019). BCR juga berfungsi untuk memantau status baterai.

Untuk kebutuhan rangkaian penunjuk jalan, BCR diatur pada mode penyimpanan listrik. Pada pengaturan ini, BCR melakukan kontrol hubungan ke semua bagian sistem (aki, panel surya, dan LED pita). Pada saat ada cahaya matahari dari pagi hingga sore hari, BCR akan mengatur energi dari panel surya untuk mengisi baterai sampai keadaan penuh (ditandai dengan nilai tegangan baterai maksimal) tanpa menyalakan LED pita. Saat radiasi matahari berkurang 
pada sore hari dan tegangan keluaran panel surya berkurang, maka BCR akan mengatur agar baterai menyalurkan daya yang tersimpan ke LED pita untuk menyalakan lampu penunjuk jalan.

Kemiringan panel surya bervariasi menurut posisi geografisnya. Untuk daerah Indonesia yang terletak disekitar garis katulistiwa, posisi panel surya cenderung datar (Rif'an et al., 2012). Orientasi dan kemiringan maksimum panel surya dapat dihitung berdasar koordinat area tersebut (lat) dan ketinggian maksimum matahari mencapai langit $(\alpha)$ untuk mendapatkan pancaran sinar matahari yang optimal (Prajogo et al., 2018; Ramadhan et al., 2016), dengan sudut deklinasi matahari $(\delta)$ yaitu $23,45^{\circ}$ (Auliq et al., 2020; Duka et al., 2018; Rif'an et al., 2012). Lokasi wisata CIP berada pada 7,7 Lintang Selatan. Rumusan untuk menghitung ketinggian maksimum matahari mencapai langit $(\alpha)$ untuk S hemisphere sebagai berikut (Auliq et al., 2020; Duka et al., 2018):

$$
\alpha=90^{\circ}+\text { Lat }-\delta
$$

dan rumusan untuk menghitung kemiringan maksimum panel surya terhadap permukaan bumi $(\beta)$ adalah sebagai berikut (Auliq et al., 2020; Duka et al., 2018):

$$
\beta=90^{\circ}-\alpha
$$

Berdasar kedua persamaan dan posisi lokasi kawasan CIP, maka diperoleh kemiringan maksimum panel surya untuk daerah ini adalah $15,75^{\circ}$. Pada desain lampu penunjuk jalan ini panel surya yang diletakkan di bagian atas perangkat diatur sehingga membentuk sudut 15 derajat terhadap permukaan tanah, dan menghadap arah Barat sesuai dengan lokasi.

Rancangan papan lampu penunjuk jalan membutuhkan LED pita sepanjang kurang dari 1 meter. Lampu LED pita yang digunakan membutuhkan daya sebesar 5 Watt per meter dengan tegangan kerja 12 Volt. Pada rancangan direncanakan LED menyala selama 5 jam, diasumsikan mulai pukul 18:00 hingga 23:00. Untuk itu daya beban adalah sebesar $25 \mathrm{Wh}$. Untuk keamanan, pada sistem PLTS dengan daya 100 Watt kebawah perlu ditambahkan faktor rugi-rugi sistem dan keamanan sebesar 20\% (Auliq et al., 2020; Roza \& Mujirudin, 2019), sehingga daya beban total adalah $30 \mathrm{Wh}$. Untuk kebutuhan daya tersebut, kapasitas minimal aki dengan tegangan kerja 12 Volt yang dibutuhkan adalah 2,5 Ah. Efisiensi keseluruhan (panel surya, baterai dan BCR) pada rancangan diasumsikan sebesar 50\%, maka idealnya disediakan penyimpanan sebesar $5 \mathrm{Ah}$. Pada rancangan ini digunakan aki dengan kapasitas $7 \mathrm{Ah}$. Panel surya 10 WP yang digunakan pada rancangan ini dengan pertimbangan efisiensi sistem sebesar $50 \%$ mampu mengisi aki dengan kapasitas 2,5 Ah hingga penuh dengan radiasi matahari selama 6 jam.

Pada saat implementasi, dibuat empat buah lampu penunjuk jalan sesuai dengan kebutuhan, yaitu mulai dari area masuk desa menuju bukit Cottok. Pada saat pelatihan, peserta dibagi menjadi empat kelompok. Tiap kelompok yang terdiri dari 2-3 orang peserta didampingi oleh seorang mahasiswa dari PS-TE UKWMS. Mahasiswa yang terlibat sudah dibekali dengan pengetahuan tentang implementasi pembuatan lampu tersebut. 
Agustine, L., Gunadhi, A., Antonia, D.L., Weliamto, W.A., Angka, P.R., Sitepu, R., Pranjoto, H., Joewono, A., Yuliati, Miyata, A.F.

Aktifitas peserta dan mahasiswa pendamping pada kegiatan pelatihan tersebut dapat dilihat pada Gambar 4, 5, 6 dan 7. Gambar 4 dan 5 menunjukkan proses pendampingan dan kegiatan peserta saat pengenalan bagian-bagian bahan. Pada Gambar 6 dan 7 menunjukkan aktivitas peserta dalam merakit kerangka lampu penunjuk jalan. Melalui tahapan perakitan tersebut, peserta juga mempelajari hal-hal yang terkait dengan kondisi bagian-bagian elektronik dan bagaimana koneksi yang baik, sehingga menjamin hasil akhir yang baik.

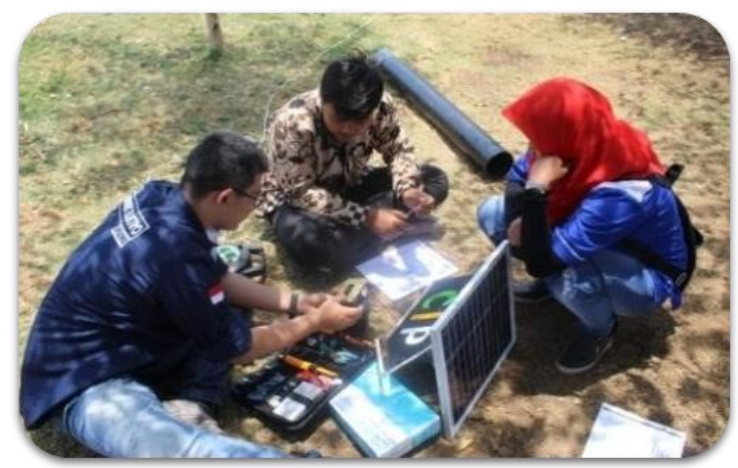

Gambar 4. Aktivitas peserta dan mahasiswa pendamping saat pengenalan bagian-bagian bahan dan ciriciri komponen

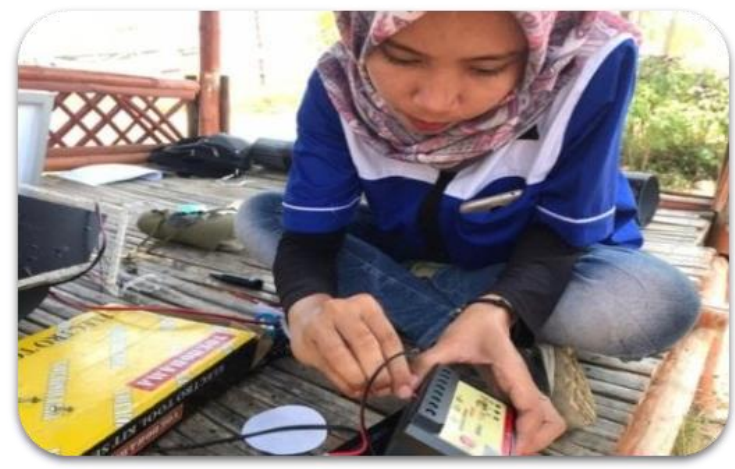

Gambar 5. Aktivitas peserta saat praktik perakitan bagian elektronik

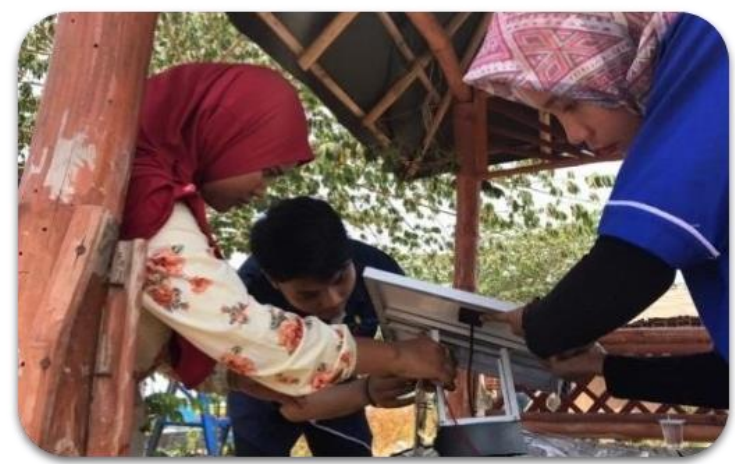

Gambar 6. Aktivitas peserta dan mahasiswa pendamping saat perakitan rangka lampu penunjuk jalan 


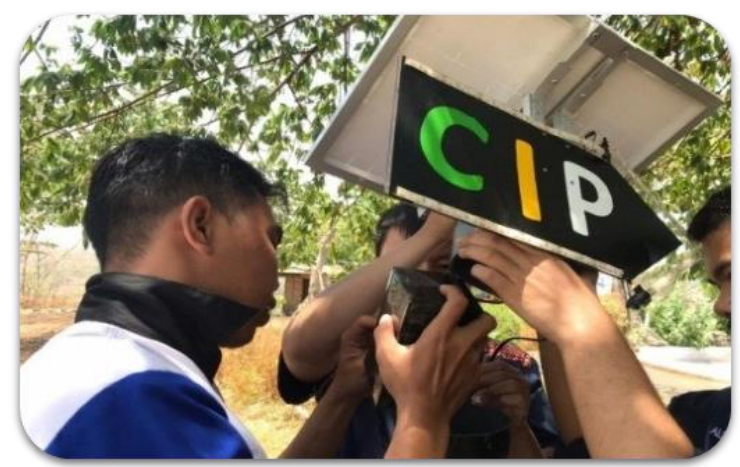

Gambar 7. Aktivitas peserta dan mahasiswa pendamping saat penempatan bagian elektronik ke dalam rangka lampu

Para peserta yang telah mengikuti kegiatan abdimas ini selanjutnya dapat berpartisipasi di program "Belajar di Lapangan" yang merupakan salah satu program wisata edukasi yang ditawarkan di wisata CIP untuk membagikan pengetahuan mereka kepada para pelajar yang mengikuti program tersebut.

Pada saat pendampingan, mahasiswa hanya memberikan petunjuk dengan sesekali memberikan contoh, dan selebihnya proses perakitan dan pemasangan lampu dilakukan oleh peserta sehingga menjadi satu kesatuan. Akhir dari proses ini adalah instalasi dari perangkat tersebut di tempat yang sudah ditentukan sebagai penunjuk jalan menuju bukit Cottok. Dalam kegiatan ini, selain mendapatkan pelatihan tentang perakitan tersebut, peserta juga dibekali dengan pengetahuan kegunaan masing-masing komponen yang ditunjukkan pada Gambar 9. Melalui aktivitas ini, peserta juga diajarkan metode untuk menyolder dengan baik sehingga hubungan kabel baik dan tahan lama. Peserta juga diajarkan mengenai desain perangkat dan penempatannya sehingga aman dari air hujan, dan pada saat yang sama terlihat menarik sehingga lebih banyak pengunjung yang tahu dan tertarik untuk naik ke bukit Cottok, baik pada siang maupun malam hari untuk menikmat wahana yang disediakan disana. Pada akhir dari kegiatan abdimas kali ini, para peserta diwawancarai mengenai kegiatan mereka. Secara umum peserta merasa mampu untuk melakukan hal yang sama, mulai dari pengenalan bahan baku, penyusunan/ pembuatan rangkaian, dan pembuatan akhir dari lampu tersebut.

Pengembangan kawasan CIP secara berkelanjutan telah memberikan dampak bagi lingkungan maupun masyarakat desa Curah Cottok dan desa sekitarnya. Bukit yang awalnya sangat gersang karena tidak ada pengairan dan belum didayagunakan pada tahun 2017 (Gambar 8) telah berubah menjadi kawasan yang hijau dan telah dimanfaatkan masyarakat (Gambar 9). 


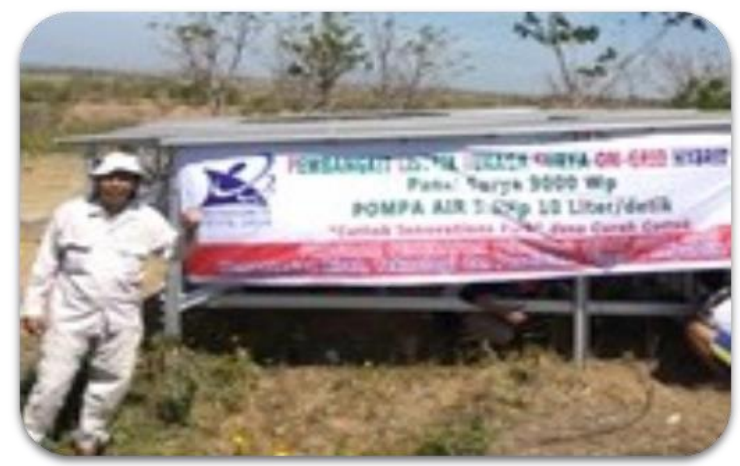

Gambar 8. Pemanfaatan kawasan bukit Cottok saat awal pengembangan tahun 2017

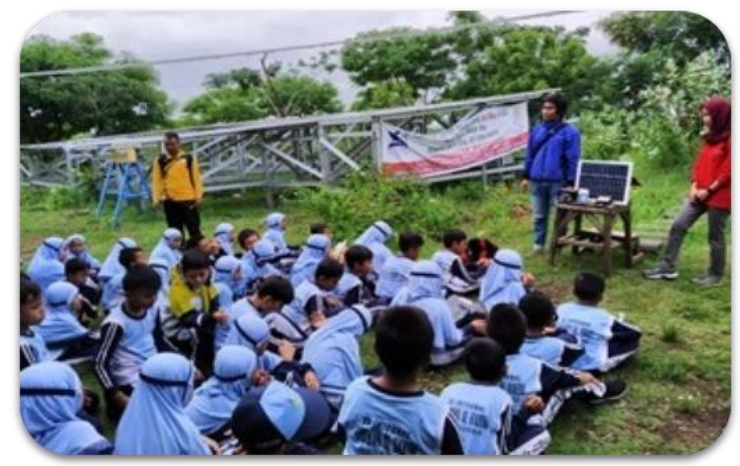

Gambar 9. Pemanfaatan sistem PLTS di bukit Cottok untuk edukasi masyarakat melalui program "Belajar di Lapangan" oleh kaum muda desa pada tahun 2019

Pengembangan diawali dengan dibangunnya PLTS yang mempunyai kapasitas 10 liter per detik untuk menarik air dari sumber air tanah pada kedalaman 40 m di puncak bukit Cottok yang terus ditingkatkan kapasitasnya (Anggorowati et al., 2021; Joewono et al., 2019). Kawasan tersebut kini telah memiliki fungsi yang memberi dampak pada masyarakat. Dampak tidak hanya dirasakan desa sekitar, namun dapat dirasakan lebih luas lagi melalui programprogram yang dikembangkan yang berawal dari kegiatan pengabdian masyarakat yang diberikan. Program-program yang diadakan di kawasan tersebut juga memberi penghidupan bagi masyarakat sekitar dengan berjualan makanan dan minuman di area wisata tersebut.

Kerjasama berkelanjutan sampai dengan tahun 2019 telah memberikan dampak positif dengan edukasi dan transfer teknologi yang dilatihkan melalui kegiatan pengabdian masyarakat. Pelatihan yang telah didapat dari kegiatan pengabdian masyarakat ditindaklanjuti oleh perangkat desa dan kaum muda desa untuk pengembangan daerah wisata CIP, sehingga dapat mewujudkan cita-cita mulianya yaitu menjadi tempat wisata edukasi teknologi menuju pencapaian visi menjadi desa yang mandiri dan beriman. Program "Belajar di Lapangan" merupakan salah satu contoh hasil tindak lanjut perangkat desa dan peserta dari progam pengabdian masyarakat yang telah diselenggarakan. Gambar 8 menunjukkan situasi pengajaran tentang teknologi tenaga surya 
dalam program "Belajar di Lapangan". Peserta kegiatan pada gambar tersebut adalah siswa SD setempat. Instruktur kegiatan ini adalah kaum muda yang sudah mengikuti pelatihan tentang pembangkit listrik tenaga surya oleh mahasiswa PS-TE UKWMS melalui program pengabdian masyarakat. Program ini terdiri dari kegiatan belajar, diskusi, dan bermain. Peserta dapat melihat secara langsung perangkat yang digunakan dan penerapan teknologi tersebut secara nyata, sehingga membantu memberikan wawasan yang utuh tentang teknologi ini.

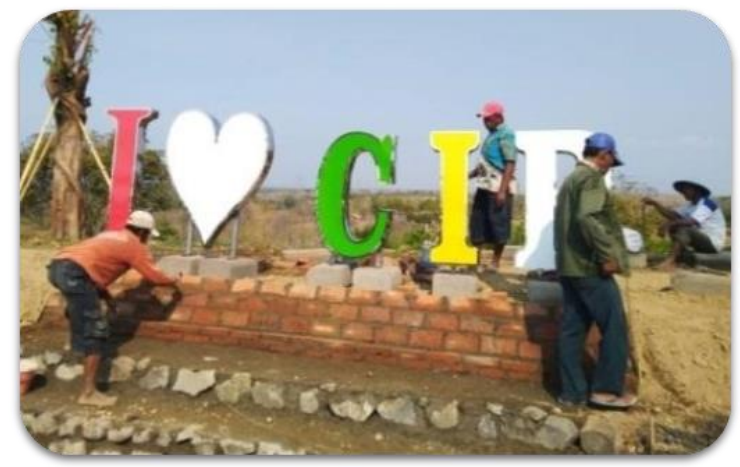

Gambar 10. Pembangunan ikon "CIP”pada akhir tahun 2019

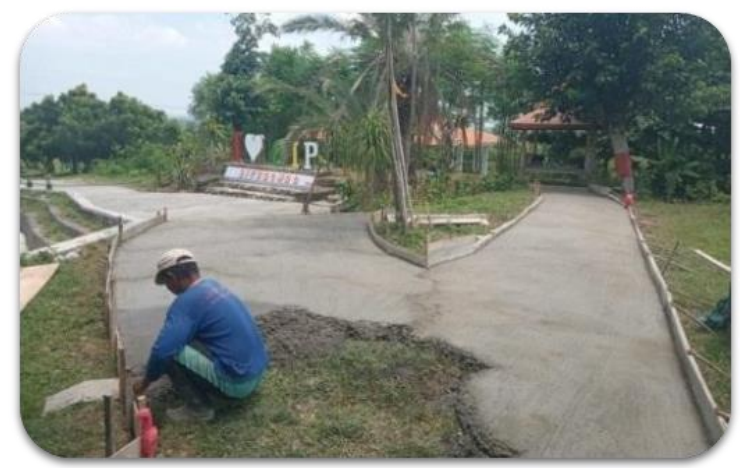

Gambar 11. Pembangunan area ikon pada akhir tahun 2020

Sejumlah teknologi juga telah dihibahkan ke desa tersebut untuk alat pelatihan masyarakat dibawah koordinasi Bumdes, diantaranya mesin pemipih jagung, mesin pengering kepala udang, dan mesin pengering kerupuk. Pengembangan lahan tandus menjadi kawasan CIP telah membuahkan hasil. Kawasan CIP telah menjadi kawasan wisata. Jumlah penduduk miskin telah berkurang menjadi 60\%. Pada tahun 2020 Bumdes Desa Curah Cottok telah meraih Bumdes terbaik peringkat 4 pada ajang Bumdes Award 2020 yang diselenggarakan oleh Institut Teknologi Sepuluh Nopember (ITS) Surabaya berkat berbagai inovasi berdampak yang telah dilakukan.

Kawasan wisata CIP kini telah dapat dikembangkan lebih luas lagi untuk jenis wisata pada malam hari dengan dukungan lampu penunjuk jalan yang dihasilkan dari kegiatan pengabdian masyarakat terakhir. Hasil lainnya dari 
kegiatan abdimas kali ini adalah berdirinya lampu ikon CIP. Ikon ini akan menjadi salah satu ciri yang mengandung filosofi kawasan sekitar, sehingga kawasan wisata ini dapat dikenal lebih luas lagi. Gambar 10 menunjukkan proses pendirian ikon yang juga merupakan hasil kerjasama antara tim pengabdian masyarakat dengan pihak desa pada akhir tahun 2019. Dampak dari pendirian ikon tersebut terlihat dari pesatnya peningkatan pengunjung dan pendapatan, sehingga pengembangan kawasan ini dapat dilakukan secara berkesinambungan. Gambar 11 menunjukkan keadaan kawasan wisata tersebut di area berdirinya ikon CIP pada akhir tahun 2020.

Foto angkasa kawasan wisata CIP seperti pada Gambar 12 dapat dilihat dengan melakukan penelusuran lewat Google Map menggunakan kata kunci "Cottok Innovation Park". Pada gambar tersebut terlihat bahwa daerah ini sudah menghijau dan dilengkapi dengan kolam renang yang airnya berasal dari air tanah bukit Cottok. Air tanah tersebut saat ini dialirkan ke puncak bukit menggunakan listrik tenaga surya dengan sekumpulan panel surya yang terlihat membentuk huruf "CIP" yang ditunjukkan oleh tanda panah. Pada gambar tersebut tulisan CIP terlihat terbalik.

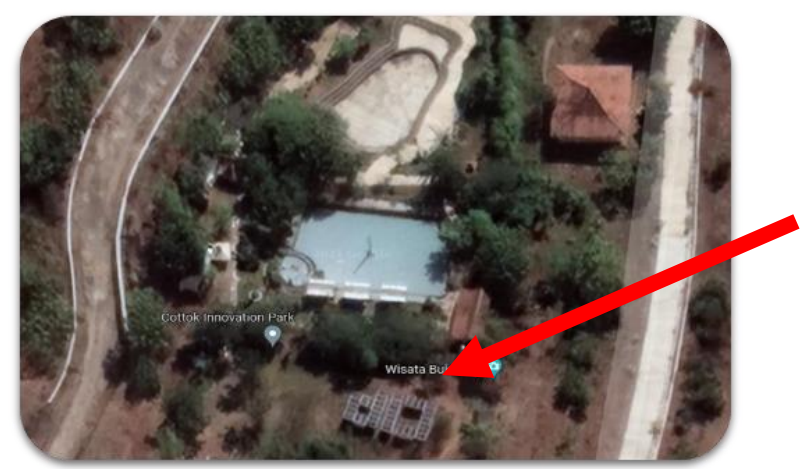

Gambar 12. Cottok Innovation Park dilihat dengan menggunakan Google Map. Panel surya "CIP" terlihat terbalik

\section{KESIMPULAN}

Dari perkembangan yang telah terjadi sejak tahun 2017 hingga saat ini, dapat disimpulkan bahwa kerjasama yang telah terjalin dan terutama kegiatankegiatan pengabdian masyarakat yang dilaksanakan telah mencapai tujuannya. Upaya perangkat desa untuk memutus mata rantai kemiskinan sudah menunjukkan hasil karena kaum muda desa sudah termotivasi untuk menggapai kehidupan yang lebih baik melalui pendayagunaan teknologi. Dengan adanya teknologi tenaga surya dan pengetahuan yang memadai tentang penggunaannya, daerah yang dulunya tertinggal dan tandus telah menjadi daerah yang lebih baik dengan ekonomi masyarakat yang lebih baik pula. Keberhasilan ini hanya dapat dicapai dengan upaya dan motivasi yang kuat dari perangkat dan sesepuh desa serta dukungan dari pihak eksternal desa secara intens dan berkelanjutan. Kerjasama dibina untuk menggali 
potensi-potensi desa dan memanfaatkannya untuk memecahkan masalah di desa tersebut.

Tindak lanjut dari program kegiatan yang telah berlangsung ini dapat berupa peningkatan kesejahteraan masyarakat sekitar melalui pelatihan lanjutan, terutama pada bidang ekonomi dan wirausaha. Masih banyak sumbangsih dari berbagai pihak dan bidang ilmu yang dibutuhkan untuk lebih mengembangkan kawasan wisata ini, sehingga membangkitkan semangat masyarakat untuk menuju kehidupan yang lebih baik, dari desa yang paling miskin di kabupaten Situbondo menuju desa maju.

\section{DAFTAR RUJUKAN}

Anggorowati, A. A., Sitepu, R., \& Joewono, A. (2021). Penggunaan Pembangkit Listrik Tenaga Surya Hybrid- Ongrid di Lahan Tandus Desa Curah Cottok. Buletin Profesi Insinyur, 4(1), 13-17. https://doi.org/10.20527/bpi.v4i2.93

Arinaldo, D., \& Christian, J. (2018). Laporan Status Energi Bersih Indonesia 2018. Proceedings Institute for Essential Services Reform (IESR). https://iesr.or.id/pustaka/laporan-status-energi-bersih-indonesia-2018

Auliq, M. A., Fitriana, \& Robitoh, S. (2020). Studi Implementasi Smart Grid Solar PV System Di Gedung G Universitas Muhammadiyah Jember. ELKOM Jurnal Teknik Elektro Dan Komputasi, 2(2), 87-95. https://doi.org/10.32528/elkom.v2i2.3444

Bappeda Provinsi Jawa Timur. (2013). Potensi dan Produk Unggulan Jawa Timur. Kabupaten Situbondo. http://bappeda.jatimprov.go.id/bappeda/wp-content/uploads/potensikab-kota-2013/kab-situbondo-2013.pdf

Darma, A. A. (2018). Analisis Potensi dan Produk Unggulan Kabupaten Situbondo. http://alvindarma4.blogspot.com/2018/12/analisis-potensidan-produk-unggulan.html

Duka, E. T. A., Setiawan, I. N., \& Weking, A. I. (2018). Perencanaan Pembangkit Listrik Tenaga Surya Hybrid Pada Area Parkir Gedung Dinas Cipta Karya, Dinas Bina Marga Dan Pengairan Kabupaten Badung. E-Journal SPEKTRUM, $5(2)$,

67-73. https://doi.org/10.24843/SPEKTRUM.2018.v05.i02.p09

Joewono, A., Sitepu, R., Angka, P. R., Nico, L., \& Wulandar, D. (2019). Alat Penyedot dan Pemfilter Air dengan Tenaga Listrik Hybrid- Bergerak. Prosiding Seminar Nasional Seri 9: Mewujudkan Masyarakat Madani Dan Lestari - Diseminasi Pengabdian, 11-18. https://dspace.uii.ac.id/handle/123456789/17323

Kementerian ESDM RI. (2018). Keputusan Menteri Energi dan Sumber Daya Mineral Republik Indonesia, no. 1567 K/21/MEM/2018 tentang Pengesahan Rencana Usaha Penyediaan Tenaga Listrik PT Perusahaan Listrik Negara (PERSERO) tahun 2018-2027.

Kementerian ESDM RI. (2020). Transformasi Energi. Energi Kolaborasi, 3, 1213. https://www.esdm.go.id/assets/media/content/content-majalahenergi-kolaborasi-edisi-iii-tahun-2020.pdf 
Naim, M. (2017). Rancangan Sistem Kelistrikan Plts Off Grid 1000 Watt Di Desa Loeha Kecamatan Towuti. DINAMIKA Jurnal IImiah Teknik Mesin, 9(1), 17-25. https://doi.org/10.33772/djitm.v9i1.3216

Prajogo, S., Utami, S., \& Pudin, A. (2018). Pengembangan Sistem Manajemen Energi Pembangkit Listrik Tenaga Surya Guna Meningkatkan Kontinuitas Listrik Rumah Tangga. Seminar Nasional Vokasi Indonesia.

Putra, Y. M. P. (2018). Desa Situbondo Canangkan Cottok Innovation Park. Republika.Co.ld. https://www.republika.co.id/berita/p24n1k284/desasitubondo-canangkan-cottok-innovation-park

Ramadhan, A. I., Diniardi, E., \& Mukti, S. H. (2016). Analisis Desain Sistem Pembangkit Listrik Tenaga Surya Kapasitas 50 WP. Teknik, 37(2), 5963. https://doi.org/10.14710/teknik.v37n2.9011

Rif'an, M., Pramono, S. H., Shidiq, M., Yuwono, R., Suyono, H., \& Suhartati, F. (2012). Optimasi Pemanfaatan Energi Listrik Tenaga Matahari di Jurusan Teknik Elektro Universitas Brawijaya. Jurnal EECCIS, 6(1), 4448. https://jurnaleeccis.ub.ac.id/index.php/eeccis/article/view/165

Roza, E., \& Mujirudin, M. (2019). Perancangan Pembangkit Tenaga Surya Fakultas Teknik UHAMKA. EJKTE Jurnal Kajian Teknik Elektro, 4(1), 16-30.

http://journal.uta45jakarta.ac.id/index.php/JKTE/article/view/1386

Sitorus, S. R. P. (2016). Perencanaan Penggunaan lahan (R. Y. Y. Maromon \& Y. Elviandri (eds.); 1st ed.). PT Penerbit IPB Press. https://www.researchgate.net/profile/Santun-

Sitorus/publication/321996261_Perencanaan_Penggunaan_Lahan/link s/5a3c948faca272dd65e4db64/Perencanaan-Penggunaan-Lahan.pdf

Sulistyaningsih, \& Yekti, G. I. A. (2017). Pemberdayaan Masyarakat dan Potensi Wilayah di Sekitar Waduk Pitaloka Berbasis Teknologi Informasi dan UMKM Menuju Desa Curah Cottok yang Agro-Eko-Wisata. Seminar Nasional Hasil Pengabdian Kepada Masyarakat. 